\title{
Expression of enterotoxin-coding genes in methicillin-resistant Staphylococcus aureus strains isolated from Mexican haemodialysis patients
}

\author{
Gloria Luz Paniagua-Contreras', Eric Monroy-Pérez ${ }^{1}$, Felipe Vaca-Paniagua', José Raymundo Rodríguez-Moctezuma²
} and Sergio Vaca ${ }^{1 *}$

\begin{abstract}
Background: Methicillin-resistant Staphylococcus aureus (MRSA) causes severe catheter-related infections in haemodialysis patients ranging from local-site infections and septic thrombophlebitis to bacteraemia but the associated virulence factors and exotoxins remain unclear.

Findings: We employed an in vitro infection model using reconstituted human epithelium (RHE) to analyse the expression profiles of 4 virulence genes and 12 exotoxin-coding virulence genes in 21 MRSA strains isolated from catheter-related infections in 21 Mexican patients undergoing haemodialysis.

All 21 strains (100\%) expressed the seg, seh, sei, eta, etb, or hla genes coding staphylococcal toxins. Eleven MRSA strains (52.3\%) expressed the sea gene coding staphylococcal enterotoxin A, and two strains (9.5\%) expressed the v8 gene coding serine protease. The tst, chp, and arcA genes coding toxic shock syndrome toxin 1, chemotaxis inhibitory protein, and arginine deiminase, respectively, were expressed in separate single strains (4.7\%). The most frequent expression profile (42.8\% of the strains) comprised seg, seh, sei, eta, etb, and hla.

Conclusion: It is likely that the SEG, SEH, SEI, ETA, ETB, and Hla toxins may play a role in MRSA catheter-related infections. Consideration of these toxins in the development of a vaccine or as targets for monoclonal antibody therapy could provide an improved therapeutic strategy for the treatment of catheter-related infections in haemodialysis patients.
\end{abstract}

Keywords: MRSA, Haemodialysis catheter, Enterotoxins

\section{Findings}

Methicillin-resistant Staphylococcus aureus (MRSA) is known to produce catheter-associated bacteraemia in haemodialysis patients because of its ability to form a biofilm in the interior of endovascular catheters [1]. $S$. aureus is able to produce several exotoxins with superantigen activity, including staphylococcal enterotoxins (SEA to SEE and SEG to SEJ) encoded by the genes sea, $s e b, s e c, s e d, s e e, s e g, s e h, s e i$, and sej; toxic shock syndrome toxin 1 (TSST-1, encoded by tst) and exfoliative toxins (ETA and ETB, encoded by eta and etb) [2]. Other virulence factors in S. aureus are encoded by the

\footnotetext{
* Correspondence: vacasergio@gmail.com

${ }^{1}$ FES-Iztacala, Universidad Nacional Autónoma de Mexico, Av de Los Barrios 1, Los Reyes Iztacala, Tlalnepantla 54090 Edo de México, México

Full list of author information is available at the end of the article
}

genes hla (alpha toxin), chp (chemotaxis inhibitory protein), $\operatorname{arc} A$ (arginine deiminase), and $v 8$ (serine protease V8) [3]. The expression of these factors is tightly regulated during growth, and the accessory gene regulator (agr) system, also known as the quorum-sensing system, plays a central role in the regulation of virulence factors [4]. The frequency of MRSA infections has increased, and nosocomial infections are now a serious problem because of the limited number of effective antibiotics available for treatment [5].

We recently analysed the expression profiles of genes encoding adhesins in MRSA strains isolated from catheter-related infections in patients undergoing haemodialysis [6]; however, it is not known whether these strains carry and express genes encoding enterotoxins. In this study, we employed an in vitro infection model using 
Table 1 Expression of pyrogenic exotoxins genes of the MRSA strains

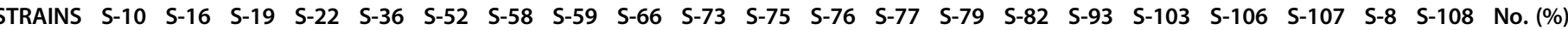

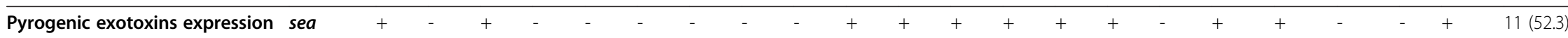

\begin{tabular}{|c|c|c|c|c|c|c|c|c|c|c|c|c|c|c|c|c|c|c|c|c|c|c|c|}
\hline & $s e b$ & - & - & - & - & - & - & - & - & - & - & - & - & - & - & - & - & - & - & - & - & - & $0(0)$ \\
\hline & $\mathrm{sec}$ & - & - & - & - & - & - & - & - & - & - & - & - & - & - & - & - & - & - & - & - & - & $0(0)$ \\
\hline & sed & - & - & - & - & - & - & - & - & - & - & - & - & - & - & - & - & - & - & - & - & - & $0(0)$ \\
\hline & see & - & - & - & - & - & - & - & - & - & - & - & - & - & - & - & - & - & - & - & - & - & $0(0)$ \\
\hline & seg & + & + & + & + & + & + & + & + & + & + & + & + & + & + & + & + & + & + & + & + & + & $21(100)$ \\
\hline & seh & + & + & + & + & + & + & + & + & + & + & + & + & + & + & + & + & + & + & + & + & + & $21(100)$ \\
\hline & sei & + & + & + & + & + & + & + & + & + & + & + & + & + & + & + & + & + & + & + & + & + & $21(100)$ \\
\hline & sej & - & - & - & - & - & - & - & - & - & - & - & - & - & - & - & - & - & - & - & - & - & $0(0)$ \\
\hline & $t s t$ & - & + & - & - & - & - & - & - & - & - & - & - & - & - & - & - & - & - & - & - & - & $1(4.7)$ \\
\hline & eta & + & + & + & + & + & + & + & + & + & + & + & + & + & + & + & + & + & + & + & + & + & $21(100)$ \\
\hline & etb & + & + & + & + & + & + & + & + & + & + & + & + & + & + & + & + & + & + & + & + & + & $21(100)$ \\
\hline Others genes expression & hla & + & + & + & + & + & + & + & + & + & + & + & + & + & + & + & + & + & + & + & + & + & $21(100)$ \\
\hline & chp & - & - & - & - & - & - & - & - & - & - & - & - & - & - & + & - & - & - & - & - & - & $1(4.7)$ \\
\hline & $\operatorname{arc} A$ & - & - & - & - & - & - & - & - & - & - & - & - & - & + & - & - & - & - & - & - & - & $1(4.7)$ \\
\hline & v8 & - & - & - & - & - & - & - & - & - & - & + & + & - & - & - & - & - & - & - & - & - & $2(9.5)$ \\
\hline
\end{tabular}


reconstituted human epithelium (RHE) to analyse the expression profiles of genes encoding pyrogenic exotoxins in our collection of MRSA strains isolated from catheter-related infections in Mexican patients undergoing haemodialysis.

The 21 MRSA strains analysed in this study were isolated from catheter-related infections in 21 Mexican patients and have been described previously [6]. Bacterial DNA was extracted using the Wizard Genomic DNA Purification Kit (Promega, Fitchburg, WI, USA).

Reconstituted human epithelium (RHE; SkinEthic Laboratories, Nice, France) consists of human epithelial cells cultured on polycarbonate filters in vitro at the air-liquid interface in serum-free conditions in a defined medium based on the MCDB-153 medium (Clonetics, San Diego, CA, USA) containing $5 \mu \mathrm{g}$ insulin $/ \mathrm{mL}$. In total, $2 \times 10^{6} \mathrm{~S}$. aureus cells suspended in $50 \mu \mathrm{L}$ of $0.1 \mathrm{M}$ phosphatebuffered saline (PBS) were inoculated onto the surface of the RHE and incubated at $37^{\circ} \mathrm{C}$ for $72 \mathrm{~h}$ under $5 \% \mathrm{CO}_{2}$ and saturated humidity. The media were changed every $24 \mathrm{~h}$.

$S$. aureus RNA purification and reverse transcription were performed as previously described [6]. The primers for real-time PCR were described previously for the following genes sea, seb, sec, sed, see, seg, seh, sei, sej, tst, eta, etb, hla, chp, arcA, and $v 8$ [3]. The Rotor-Gene SYBR Green PCR kit (Qiagen, Hilden, Germany) was used for real-time PCR expression profiling according with the manufacturer's instructions. gyrB (DNA gyrase B) was used as a reference gene. S. epidermidis ATCC 35984 and Escherichia coli ATCC 11775 were used as negative controls. S. aureus ATCC 33592 was used as the positive control.

All MRSA strains $(\mathrm{n}=21)$ expressed 6 genes, that is, seg, seh, sei, eta, etb, and hla, of the 16 genes studied during in vitro infection of RHE. tst, chp, and $\operatorname{arcA}$ were expressed in separate single strains (4.7\%), and $v 8$ was expressed by 2 strains (9.5\%; Table 1 ). Six distinct expression profiles of virulence markers were found during MRSA infection of RHE. Profile 1, composed of 6 genes (seg, seh, sei, eta, etb, and $h l a$ ), was seen for nine (42.3\%) MRSA isolates, and profile 2, composed of 7 genes (sea, seg, seh, sei, eta, etb, and hla), was seen for seven strains (33.3\%). Profile 3, formed by 8 genes (sea, seg, seh, sei, $e t a$, etb, hla, and v8), was found in $2(9.5 \%)$ MRSA isolates. Three distinct profiles comprising 7-8 expressed genes in only one MRSA strain each were also found.

MRSA strains previously reported as belonging to the spa type $\mathrm{t} 895$ and having identical pulsed-field gel electrophoresis (PFGE) profiles (S-22 and S36; S59 and S-66) [6] showed identical expression profiles of pyrogenic exotoxin genes. Additionally, the toxin gene expression profiles of MRSA strains S-77, S-79 and S-82, which have a distinct PFGE profile but the same spa type (t895) [6], differed by one gene: $\operatorname{arcA}$ (S-79) or chp (S-82).

\section{Expression of enterotoxin-coding genes in MRSA}

Catheter-related bacteraemia caused by MRSA in patients who have end-stage renal disease and are undergoing chronic haemodialysis is a serious health problem [1]. Several studies have characterised $S$. aureus virulence factors in animal models [7-9]. In this study, we employed an in vitro infection model using RHE to analyse the expression profiles of genes encoding exotoxins in MRSA strains isolated from catheter-related infections in Mexican patients undergoing haemodialysis. All of the MRSA strains studied here expressed an important set of virulence factors. All of the strains expressed three staphylococcal enterotoxins (SEG, SEH, and SEI), two exfoliative toxins (ETA and ETB), and the alpha toxin (Hla) (Table 1). We had previously showed that these strains also expressed the global regulator of multiple virulence factors, agr (18/21 strains expressed agr I, $3 / 21$ expressed agr II) [6], which had previously been associated with suppurative infections [10]. We also showed that 12 of 21 of these strains harboured SCCmec type IV, 6 of 21 harboured SCCmec type II, and 3 of 21 harboured SCCmec type I [6].

The frequency of genes encoding toxins has been previously described for $S$. aureus strains related to different types of infections [3,11]; however, to our knowledge, this is the first time that the expression of genes encoding pyrogenic toxins in MRSA strains associated with catheter-related infections was profiled.

The results presented here show that it is likely that the SEG, SEH, SEI, ETA, ETB, and Hla toxins may play a role in the pathogenesis of MRSA catheter-related infections. Comparative quantification of the expression of these genes in these MRSA and in other S. aureus isolates could further support this point. Considering these toxins in the development of a vaccine, or as targets for monoclonal antibody therapy, could provide an improved therapeutic strategy for the prevention or treatment of catheter-related infections.

\section{Availability of supporting data}

The data supporting the results of this study are included within this article.

\section{Competing interests}

The authors declare that they have no competing interests.

\section{Authors' contributions}

GLPC, EMP and JRRM have made substantial contribution to acquisition of data. FVP has made substantial contribution to analysis and interpretation of data. SV has been involved in drafting the manuscript. All authors have read and approved the final manuscript.

\section{Acknowledgements}

This work was supported by grants from UNAM-DGAPA-PAPIIT IN218211 and PAPCA FES Iztacala, UNAM 


\section{Author details}

'FES-Iztacala, Universidad Nacional Autónoma de Mexico, Av de Los Barrios 1, Los Reyes Iztacala, Tlalnepantla 54090 Edo de México, México. Instituto Mexicano del Seguro Social, G. Baz esq. F. Gómez, Tlalnepantla, Edo de México, México.

Received: 21 July 2014 Accepted: 5 November 2014

Published online: 25 November 2014

\section{References}

1. Parker MG, Doebbeling BN: The challenge of methicillin-resistant Staphylococcus aureus prevention in hemodialysis therapy. Semin Dial 2012, 25:42-49.

2. Pinchuk IV, Beswick EJ, Reyes VE: Staphylococcal enterotoxins. Toxins 2010, 2:2177-2197.

3. Campbell SJ, Deshmukh HS, Nelson CL, Bae IG, Stryjewski ME, Federspiel J, Tonthat JT, Rude TH, Barriere SL, Corey R, Fowler VG Jr: Genotypic characteristics of Staphylococcus aureus isolates from a multinational trial of complicated skin and skin structure infections. J Clin Microbiol 2008 46:678-684.

4. Ji G, Beavis RC, Novick RP: Cell density control of staphylococcal virulence mediated by an octapeptide pheromone. Proc Natl Acad Sci U S A 1995, 92:12055-12059.

5. Gould IM: The clinical significance of methicillin-resistant Staphylococcus aureus. J Hosp Infect 2005, 61:277-282.

6. Paniagua-Contreras GL, Monroy-Pérez E, Vaca-Paniagua F, RodriguezMoctezuma JR, Negrete-Abascal E, Vaca S: Implementation of a novel in vitro model of infection of reconstituted human epithelium for expression of virulence genes in methicillin-resistant Staphylococcus aureus strains isolated from catheter-related infections in Mexico. Ann Clin Microbio Antimicrob 2014, 13(1):6. doi:10.1186/1476-0711-13-6.

7. Burian M, Rautenberg M, Kohler T, Fritz M, Krismer B, Unger C, Hoffmann WH, Peschel A, Wolz C, Goerke C: Temporal expression of adhesion factors and activity of global regulators during establishment of Staphylococcus aureus nasal colonization. J Infect Dis 2010, 201:1414-1421.

8. Voyich JM, Otto M, Mathema B, Braughton KR, Whitney AR, Welty D, Long RD, Dorward DW, Gardner DJ, Lina G, Kreiswirth BN, De Leo FR: Is PantonValentine leukocidin the major virulence determinant in communityassociated methicillin-resistant Staphylococcus aureus disease? J Infect Dis 2006, 194:1761-1770.

9. Labandeira-Rey M, Couzon F, Boisset S, Brown EL, Bes M, Benito Y, Barbu EM, Vazquez V, Höök M, Etienne J, Bandenesch F, Bowden MG: Staphylococcus aureus Panton-Vanlentine leukocidin causes necrotizing pneumonia. Science 2007, 315:1130-1133.

10. Jarraud S, Mougel C, Thioulouse J, Lina G, Meugnier H, Forey F, Nesme X, Etienne J, Vandenesch F: Relationships between Staphylococcus aureus genetic background, virulence factors, agr groups (alleles), and human disease. Infect Immun 2002, 70:631-641.

11. Sauer P, Síla J, Stosová T, Vecerová R, Hegnar P, Vágnerová I, Kolár M, Raclavski V, Lovecková Y, Koukalová D: Prevalence of genes encoding extracellular virulence factors among meticillin-resistant Staphylococcus aureus isolates from the University Hospital, Olomouc, Czech Republic. J Med Microbiol 2008, 57:403-410.

doi:10.1186/s12941-014-0055-z

Cite this article as: Paniagua-Contreras et al:: Expression of enterotoxincoding genes in methicillin-resistant Staphylococcus aureus strains isolated from Mexican haemodialysis patients. Annals of Clinical Microbiology and Antimicrobials 2014 13:55.

\section{Submit your next manuscript to BioMed Central and take full advantage of:}

- Convenient online submission

- Thorough peer review

- No space constraints or color figure charges

- Immediate publication on acceptance

- Inclusion in PubMed, CAS, Scopus and Google Scholar

- Research which is freely available for redistribution

Submit your manuscript at www.biomedcentral.com/submit
C) Biomed Central 